\title{
Beyond Divine Command Theory: Moral realism in the Hebrew Bible
}

Author:

Jaco W. Gericke ${ }^{1}$

\section{Affiliation:}

${ }^{1}$ Faculty of Humanities,

North-West University

(Vaal Triangle Campus),

South Africa

\section{Correspondence to: \\ Jaco W. Gericke}

e-mail:

21609268@nwu.ac.za

Postal address:

22 Dromedaris, Toon

van den Heever Street,

Sasolburg, 1947, South

Africa

\section{Keywords:}

Divine Command

Theory; moral realism;

Hebrew Bible; metaethical

reflection; moral

epistemology

\section{Dates:}

Received: 30 Mar. 2009

Accepted: 22 May 2009

Published: 10 Sept. 2009

How to cite this article: Gericke, J.W., 2009, 'Beyond divine command theory: Moral realism in the Hebrew Bible', HTS Teologiese Studies/ Theological Studies 65(1), Art. \#160, 5 pages. DOI: 10.4102/hts.v65i1.160

\section{This article is available} at:

http://www.hts.org.za
(C) 2009. The Authors. Licensee: OpenJournals Publishing. This work is licensed under the Creative Commons Attribution License.

\section{ABSTRACT}

Philosophical approaches to ancient Israelite religion are rare, as is metaethical reflection on the Hebrew Bible. Nevertheless, many biblical scholars and philosophers of religion tend to take it for granted that the biblical metaethical assumptions about the relation between divinity and morality involve a pre-philosophical version of Divine Command Theory by default. In this paper the author challenges the popular consensus with several arguments demonstrating the presence of moral realism in the text. It is furthermore suggested that the popular consensus came about as a result of prima facie assessments informed by anachronistic metatheistic assumptions about what the Hebrew Bible assumed to be essential in the deity-morality relation. The study concludes with the observation that in the texts where Divine Command Theory is absent from the underlying moral epistemology the Euthyphro Dilemma disappears as a false dichotomy.

\section{INTRODUCTION

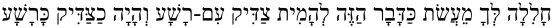

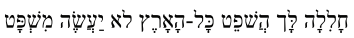

'Far be it from you to act in this way; to slay the righteous with the wicked, that so the righteous should be as the wicked. Far it be from you; shall not the Judge of all the earth do justly?' (translation by author)

The term 'morality' does not appear in the Hebrew Bible. That does not mean, however, that the concept of morality is missing altogether. Yet if by the term we understand the coherent and critical philosophical reflection on the nature of right and wrong behaviour, then the Hebrew Bible, with its non-philosophical format, literary variety, historical variability, sociocultural complexity and theological pluralism, can be immensely problematic in any attempt to provide a unified 'biblical' philosophical perspective on the relation between religion and morality. Not surprisingly, in biblical ethics questions of analytic ethics, or metaethics, tend to be bracketed (Barton 2003:45). In fact, biblical theology as such tends to be characterised by a pernicious anti-philosophical sentiment, which in turn explains the current lamentable absence of an independent and officially recognised philosophical approach to the study of ancient Israelite religion (cf. Barr 1999:146-171; Gericke 2007:669-688; Knierim 1995:492). Consequently, contemporary biblical scholarship offers little in the way of an in-depth descriptive philosophical analysis of the moral assumptions underlying the religious beliefs, concepts and practices encountered in the Hebrew Bible.

\section{A POPULAR CONSENSUS}

Despite the fact that no-one has ever written a metaethics of ancient Israelite religion there seems to exist a popular consensus involving the belief that the Hebrew Bible, by default, presents us with a historical precursor to what nowadays is known in moral philosophy and philosophy of religion as 'Divine Command Theory' (DCT) (see Adams 1987; Alston 1989, 1990:303-326; Arthur 2005:1523; Audi \& Wainwright 1986; Copan 2003:295-304, Hare 1997, 2008; Kant 1993, Kierkegaard 1985; Kretzmann 1983; Leibniz 1951; Mackie 1977, Morris 1987, 1991; Morriston 2001:127-138; Mouw 1970:6166, 1990; Murphy 1998:3-27; Nielsen 1973; Quinn 1979:305-325, 1987; Stump 2001:530-550; Wainright 2005; Wierenga 1989, 2003:387-407; Zagzebski 2004; and others). It is not that biblical scholars classify the divinity-morality relation in the text with the concept of DCT, rather, in their theological claims they seem to imply that in ancient Israelite religion the divine will was assumed to be the ultimate foundation of morality, i.e., that human actions were considered morally good if and only if YHWH willed or commanded them ( $c f$. Davies 2000:20; Otto 1994:passim). Hence one typically encounters prominent biblical theologians over the past 50 years insinuating that $\mathrm{YHWH}$ and the moral order were inextricably related:

The power of the good rests entirely on the recognition of God as the one who is good. Of moral behaviour for the sake of an abstract good there is none.

(Eichrodt 1967:316)

The ancient people, like many today, would not be prone to distinguish sharply between morality and religion. What is morally right to do is so because God wills it or because it is consistent with the divinely ordained structure of the world.

(Knight 1982:55)

Also, the Old Testament is not familiar with the concept of doing good for the sake of the good; rather it is YHWH's will that lays claim to human lives. Fixed orders are established by YHWH.

(Preuss 1992:191)

To say that ethical obligation is obedience to the will of the national God is to say that it is not the observation of...universal human norms.

(Barton 2003:46) 
Interestingly, many philosophers of religion (both theistic and atheistic) have uncritically followed suit and take it for granted that the historical precursor to Judeo-Christian versions of DCT is the Hebrew Bible itself (e.g. Hare 2008; Quinn 1979:305325, 1987; Stump 2001:530-550). Many introductory discussions on DCT assume as much, and even offer as illustration references to texts in the Hebrew Bible in which moral norms are apparently acquired solely via divine commands, e.g. the giving of the Ten Commandments. Strong arguments for the presence of DCT in the text include the giving of seemingly unnecessary commands (as to Adam and Eve or the rituals of Leviticus) and even seemingly immoral commands (e.g. the commanding of Abraham to sacrifice Isaac, of the Israelites to plunder the Egyptians, the slaughtering of the Canaanites, Hosea being told to marry a prostitute, etc.; see Hare 2008; Kretzmann 1983; Quinn 1987). In philosophical terms this would mean that the Hebrew Bible took for granted a subjectivist yet universalist form of cognitivism that one might contrast with other forms of ethical subjectivism (e.g. ideal observer theory, moral relativism, and individualist ethical subjectivism), moral realism (which claims that moral propositions refer to objective facts, independent of anyone's attitudes or opinions), error theory (which denies that any moral propositions are true in any sense), and non-cognitivism (which denies that moral sentences express propositions at all).

That the Hebrew Bible associates the right actions with what finds favour in the eyes of YHWH cannot reasonably be denied. However, as Wierenga (1989:215) implied, there is more than one way of interpreting the divinity-morality relation even given DCT (hence strong and weak versions of the theory). This is also readily apparent from any attempt to answer Socrates' question to Euthyphro in Plato's dialogue (Plato 1981), which was subsequently adapted to become what is now called the 'Euthyphro Dilemma'. In the context of the Hebrew Bible it involves the following question: Did YHWH command something because it was moral, or was something moral because it was commanded by $\mathrm{YHWH}$ ?

Due to the problems that both of the possible responses to this question are said to raise for DCT (e.g., moral relativism or redundant divine revelation), much has been written in an attempt to respond to the dilemma within the context of Christian philosophy of religion (see the discussions in Adams 1999; Frame 1993; Helm 1981; Kretzmann 1983; Quinn 1978; Wainright 2005 and Wierienga 1989). Curiously, however, I could not find any corresponding concern in biblical ethics in which someone tried to establish what a given text in the Hebrew Bible might imply in response to Euthyphro's Dilemma. Consequently, I would like us to consider two questions as our research problem:

1. Is DCT the only or default metaethical perspective on the relation between divinity and morality in the Hebrew Bible?

2. Do some texts in the Hebrew Bible offer us any hints as to which (if any) of the two possible options presented by Euthyphro's Dilemma are implied to be correct?

With these questions in mind I wish to challenge the popular consensus by offering a hypothesis, suggesting that the classification of the Hebrew Bible's metaethics as in toto a form of DCT involves the fallacies of anachronism and hasty generalisation. I furthermore suspect that the errant reading resulted from prima facie assessments informed by post-biblical philosophical-theological re-interpretations of the essentially alien historical metatheistic assumptions of ancient Israelite religion. Moreover, it is possible to show that many texts in the Hebrew Bible presuppose moral goodness as not in fact something identical to the property of being contrary to the divine will. Instead, in these texts both the deity and the divine commands were non-tautologically predicated as 'good' just in case they instantiated goodness as an accidental property, ultimately assumed to be located in an independent and stable transworld moral order.

\section{ARGUMENTS FOR MORAL REALISM}

Given the limitations of time and space applicable to this paper I shall be offering only one or two illustrations from the biblical text per argument. The quotations from the Hebrew Bible are not intended as proof-texts allowing for generalisations in order to prove that moral realism is the only biblical perspective on the deity-morality relation. Nor am I trying to argue that moral realism has biblical roots and is therefore philosophically credible. Conversely, I am not trying to prove that the basic idea of DCT is absent from the Hebrew Bible altogether or even that it is philosophically outdated. Rather, my aim is purely descriptive and historical, and I make a selective and cursive reference to particular texts only to verify the presence of moral realist motifs in the biblical discourse in a way that is suggestive of the possibility that the same motifs might well be more pervasively attested than popular prima facie correlations to DCT seem to imply.

\section{The argument from the non-tautological predication of goodness}

A useful point of departure is to ask whether there are any examples in the Hebrew Bible of the non-tautological predication of goodness as an extrinsic property of $\mathrm{YHWH}$ based on an alleged synthetic a posteriori religious epistemology. If so, it follows that moral goodness was indeed assumed to be something independent from the deity, and with reference to which he could be called 'good' (or not). In this regard cognisance should be taken of the fact that we do indeed encounter such a predication, e.g. in Psalm 34:9:

$$
\begin{aligned}
& \text { פעמי וראו כי-טוב יהוה Thaste and see that YHW is good; }
\end{aligned}
$$

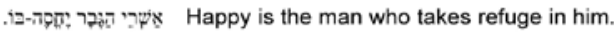

The above text assumes that the implied reader already has an idea of what goodness is quite apart from $\mathrm{YHWH}$ and with reference to which it could be determined whether the deity is in fact good or not. This means that the knowledge that $\mathrm{YHWH}$ is good was not assumed to be the result of analytical a priori reasoning. To state as the Psalmist does that $\mathrm{YHWH}$ is good (and to presuppose that the claim is in theory open to falsification) would not even have been considered meaningful were the goodness of YHWH believed to be a logically necessary property of absolute divinity. That is, if $\mathrm{YHWH}$ was assumed to be good by definition - if goodness was assumed to be in the logical constitution of the concept of deity - the stating of the proposition that YHWH is good is as superfluous as confessing that water (in its non-solid state) is wet.

\section{The argument from generic atheodicy by appeals to the moral order}

The second argument for moral realism concerns textual examples of instances where God and the gods are charged with moral wrongdoing within a case made by appealing to an objective moral order vis-à-vis deity. Here we should remember that, contrary to philosophical theology, the use of the terms for deity in their generic sense, with reference also to $\mathrm{YHWH}$, presupposes YHWH to be part of a genus or natural kind. Crude as it may sound, the extension of the generic concept of godhood did in fact frequently include more than $\mathrm{YHWH}$ alone. Philosophical monotheism is not presupposed in the texts and divinity is predicated in a variety of senses also to the gods of other nations (Jdg 11:24), a second generation of divine beings (Gn 6:1-4), members of the divine council (Ps 82:1, 6), the king (Ps 45:7), household spirits (Ex 20:11), spirits of the dead (1 Sm 28:13), and demons (Dt 32:8). When we consider the relation between divinity and morality in the Hebrew Bible we should take cognisance that the nature of divinity was often assumed to be instantiated in, but not only in, the nature of YHWH. Of course, many Bible translations are seriously ideological in agenda in that they render the generic term for divinity with a capital G when used of YHWH, even when it is clearly not 
a proper name (the god of Israel). Translations also substitute the generic term when applied to praeternatural or human entities with euphemisms, e.g. 'judges', 'angels', 'mighty ones' or 'heavenly beings'. This obscures the divinity-morality relation, e.g. as in Psalm 58:2:

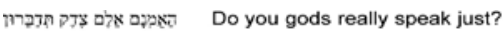

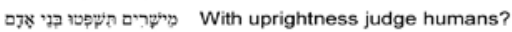

Many translations of this psalm contain references to 'judges' or 'rulers'. Yet in this text (as in many others in the Hebrew Bible) the existence of divine beings other than $\mathrm{YHWH}$ is taken for granted. It is also taken for granted that the gods are not by definition moral, which in turn presupposes the existence of a moral order vis-à-vis divinity, and with reference to which divine acts could be judged. The gods may be able to do what they like because they have the power - but that still does not mean that whatever they do is by definition good. Might was not assumed to make right and the appeal to the moral order in the charges against the gods suggests a form of moral realism where right and wrong are what they are irrespective of divine whim. A similar scenario is found in Psalm 82:

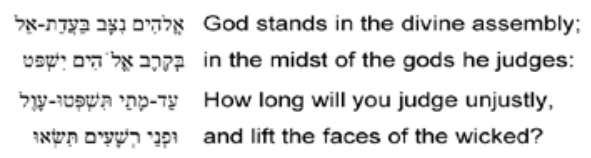

Again, many translations try to evade the 'theodiversity' of the 'divine condition' implicit by rendering 'gods' with a host of more 'orthodox' substitutes. The Hebrew, however, is clear for it presupposes the entities to be immortal prior to the divine judgment (Ps 82:6). Moreover, that gods could be caught behaving badly suggests moral realism. And lest someone objects, by pointing out that in neither of the above instances is YHWH himself being accused of doing wrong; the fact is that there are such texts, e.g. Psalms 44 and 89, in which the psalmists blatantly accuse the god of Israel of betraying the covenant. In both Psalms 44 and $89 \mathrm{YHWH}$ is at the receiving end of the critique, again presupposing the justification of the charges as coming from the appeal to what is given in the moral order. So it would seem that there are texts in the Hebrew Bible where even divinity could be judged with reference to a supposedly universal moral norm.

\section{The argument from divine mutability}

The third argument for moral realism takes its cue from the second, taking seriously the metaethical presuppositions underlying the Hebrew Bible's mythological motif of divinity as 'judge'. Consider the role of a judge vis-à-vis the law - a judge does not make the law, neither does a judge determine good or bad absolutely, nor can morality be defined with reference to the person of the judge. Rather, a judge acknowledges the law as it exists independent of him, without him being above the law. This was also often considered to be the case with the divine judge in the Hebrew Bible. A classic example appears in Genesis, where Abraham appeals to the moral order to prevent $\mathrm{YHWH}$ from what is understood to be an act of immoral retribution:

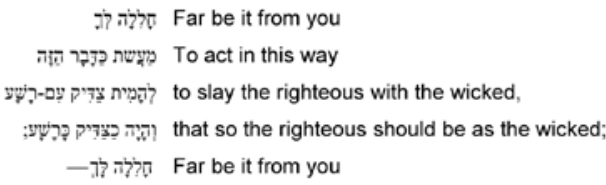

Presupposing DCT, how could Abraham make a case? Can DCT explain why the divine judge can be 'morally' taken to task through disobedience? Why did Abraham not modify his view of what is just? Surely it is because the text assumes that justice is a good thing and that its goodness is determined by the moral order independent of YHWH. A similar scenario of corrective chutzpah is attested between $\mathrm{YHWH}$ and Moses deliberating on an appropriate punishment in the 'Golden Calf' incident. First there is the divine command in Exodus 33:10:

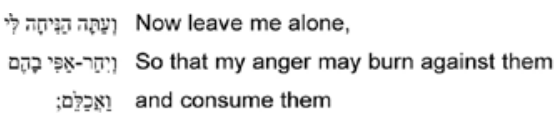

Now, on DCT, the 'moral' thing to do would have been for Moses to leave immediately. Moses, however, like Abraham, frustrates the divine will and convinces $\mathrm{YHWH}$ qua divine judge regarding the correct decision. Thus we read in Exodus 33:11:

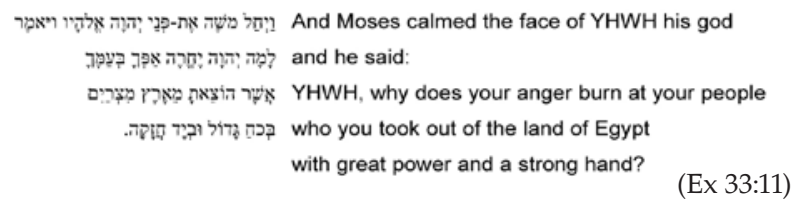

After reminding YHWH how his reputation would suffer in the face of the foreign peoples had he now destroyed the Israelites and broken the promise to Abraham, Moses' disobedience to the Divine Command to be left alone has the following result (Ex 33:14):

\section{And YHWH repented of the evil}

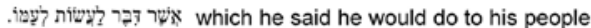

A scenario like this may be crude to the modern philosophical theologian and indeed apologists, as since the times of the Hebrew Bible itself they have sought to re-interpret the idea of $\mathrm{YHWH}$ changing his mind. My concern here is not divine immutability or its opposite, but rather the implication of the text that disobedience to the Divine Command can be a good thing for both the deity and for his subjects. On DCT, Moses definitely acted immorally However, if we presuppose that the metaethical assumptions of this text operated with a form of moral realism and a belief in a moral order independent of the deity, then the allowance for disobedience and debate with an implicit appeal to what is the right thing makes good sense. Another good example of similar pious 'back-chatting' with fortuitous consequences can be found in Amos 7:1-3.

\section{The argument from goodness as a stable transworld property}

A fourth argument for moral realism concerns the stable actual worlds-in-the-text identity of the extension of the concept of goodness. Consider the moral status of the virtues vis-à-vis the deity as mentioned in Psalm 15:1-3, where we read:

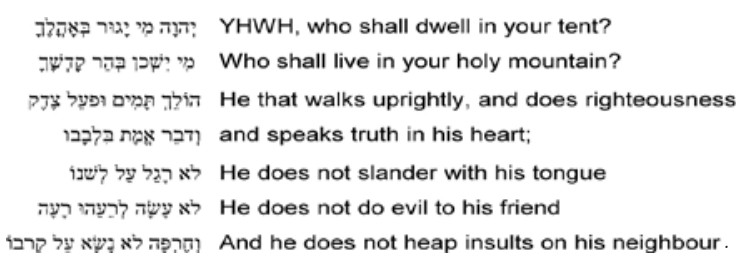

In this text it seems that YHWH was assumed to command these acts because they are moral and because YHWH was assumed to be a moral god. To be sure, the Psalm firstly intends to demonstrate YHWH's moral requirements but it does not seem to imply that, had YHWH willed the opposite, the divine will could change the moral status of the particular acts. Rather, what would change is the view of the deity as (only) moral, as we saw the case to be in Psalms 44 and 89 (see Davidson 1997:12). Aside from Psalm 15 ( $c f$. Ps 24), the stability of the moral order 
vis-à-vis the possible vicissitudes of accidental divine moral properties are clearly assumed in the text which reads:

שלקכח חבוֹת אל Has God forgotten to be gracious?

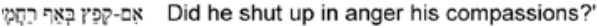

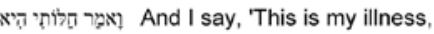

The changing of the right had of the most high."

In this text the imaginary scenario of God ceasing to be 'good' is assumed to occur in at least one possible world, e.g. in Psalm 77:9-10. Yet across all possible worlds compassion and mercy are considered virtues. Thus the entire psalm presupposes and depends on the idea of an objective moral order in relation to which YHWH appears to have changed and with reference to which his nature may be described. Without this assumption there would be no reason for the consternation the psalmist believed himself to be in (see Crenshaw 1980, 1983, 1984).

\section{The argument from 'bad' divine commands}

In non-fundamentalist biblical theology it is taken for granted that some texts in the Hebrew Bible did not assume YHWH to be perfect in goodness in that he was at times held responsible for the actualisation of not only natural but also moral evil (Gericke 2005:65-92). In the context of ancient Israelite religion, both philosophical theology's 'perfect-being theology' and the problem of evil in its classical formulation are anachronistic as the Hebrew Bible often assumed good and evil to be complimentary rather than incompatible properties of the divine nature (see Carroll 1991:45 on Is 45:7). In this regard, particularly relevant to this discussion are those texts depicting YHWH as issuing 'bad' commands. On the one hand, this sometimes involved YHWH's commands to spiritual entities to commit immoral acts, e.g. in texts like Job 1-2 and 1 Kings 22:19-22. On the other hand, on occasion, it also involved the divine commands to human beings considered as immoral, e.g. as in Ezekiel 20:25:

\section{] Wherefore I gave them also statutes that were not good, and ordinances} whereby they should not live;

In the context of Ezekiel 20 these 'bad' divine commandments are previously said to have been issued because of sin (Ezk 20:24). Yet the very possibility of divine commands being not good (irrespective of the motive for issuing them) certainly complicates DCT's equation of the good with whatever the deity commands. Even if YHWH's act is assumed to be fair and just this changes nothing about the fact that the divine command itself could not be looked to in order to determine what is moral. So whatever we think about the nature of the deity himself implicit in this text, the divine commands themselves were not assumed to instantiate the property of goodness just in case they were issued by $\mathrm{YHWH}$. The good was therefore assumed to exist vis-à-vis the commands with reference to which they themselves could be judged, namely as being either good or not

\section{The argument from relative mediatory functionality in moral epistemology}

The final argument pertains to the way in which the concept of goodness is predicated of the divine commands themselves. Good illustrations in this regard come from the so-called Torah Psalms, especially Psalms 19 and 119. In Psalm 19:9 we read:

\section{The precepts of YHWH are right, rejoicing the heart;}

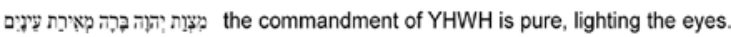

On what grounds and with what criteria are the above claims made? Do they not presuppose that the concept of what is right and pure is already possessed and that the nature of the divine law fulfills all the necessary conditions for its application? If the divine ordinances determined what is right and pure, how does it make sense to add the superfluous detail predicating these qualities of the commands themselves? Surely there must have been sufficient reason to assess the commands as such, other than this again being an allegedly tautological predication.

The same trend continues in Psalm 119, where the divine commands are in the centre of the psalmist's meditations. The ascription of the property of good to the commands and laws of YHWH also presupposes that these were judged to be good with reference to the moral order itself and not because it went without saying:

\section{Turn away my reproach which I dread;}

for your ordinances are good.

How could the psalmist need to imply the reproaches are not good if whatever the deity did was good by definition? Why did he have to state that the divine ordinances instantiate the property of goodness if it was an essential and necessary property and goodness was in the logical constitution of the concept of divine commands? Morality in the Psalms is often equated with and discerned with reference to the divine commands. Yet we often find the foundations for the good being deferred:

1. The divine commands are good because they reveal the divine will

2. The divine will is good because it reveals the divine nature

3. The divine nature is good because $x$ (where $x$ is a sufficient reason for the predication)

On DCT assumptions the buck stops here and there is no sufficient reason as to why the divine nature is to be called good; it is good by definition, whatever it may happen to be in all possible worlds. However, in terms of moral realism the equation of the good with the divine commands looks a little different and the sufficient reason for the deity being called good is assumed to be the correspondence of his character with what is required by the moral order in itself $(\mathrm{x})$. Not surprisingly, a closer inspection of the biblical data reveals the following subtle distinctions to be presupposed in many texts:

4. The divine commands mediate (not create) moral norms

5. The divine will corresponds to (not causes) what is good

6. The divine nature instantiates (not defines) the property of goodness

On this reading it would mean that it is not the deity or the divine commands that ultimately create the moral order - rather it is humans who, from their point of view, could determine what is good by referring to the divine commands, which were called good because they corresponded to the moral order.

\section{CONCLUSION}

Together these arguments cumulatively demonstrate the presence of marked traces of moral-realist assumptions in the Hebrew Bible showing that DCT was not the only metaethical trajectory operative in the history of the ancient Israelite religion. That the particular kind of moral realism involved had little in common even with weak versions of DCT, where the deity also has a primarily mediatory function, should be readily apparent from the alien metatheistic assumptions in ancient Israelite religion on which its moral-realist metaethical assumptions are based. Yet because DCT is anachronistic in the context of the Hebrew Bible, the upside is that in the context of the moralrealist trajectories in ancient Israelite religion the Euthyphro's Dilemma qua dilemma is in fact a pseudo-problem. For while the Hebrew Bible often implies that YHWH commanded something because it is good the deity was not made redundant, thereby as is the case with DCT when this divinity-morality relation is opted for. The reason for this is that, unlike what is assumed in Euthyphro's Dilemma, the ancient Israelites were 
not optimists in their religious epistemology. Even though the moral order was believed to have existed independent of the divine, the divine will - if the deity was of the moral type was still believed to be humanity's only access to that order. The deity was thus assumed to function in relation to the moral order as an instructor, a mediator, a judge and an authority on right and wrong - not as its creator. From this it follows that at least in the context of those texts in the Hebrew Bible where moral realism is presupposed, the Ethyphro Dilemma indeed represents a false dilemma. But then not as Aquinas suggested, because goodness is an essential part of the divine nature, but because the underlying moral epistemology assumed that humans needed good gods to tell them what the good life is all about.

\section{REFERENCES}

Adams, R., 1987, The virtue of faith and other essays in philosophical theology, Oxford University Press, New York.

Alston, W., 1989, Divine nature and human language: Essays in philosophical theology, Cornell University Press, Ithaca.

Alston, W., 1990, 'Some suggestions for divine command theorists', in N. Beaty (ed.), Christian theism and the problems of philosophy, pp. 303-326, University of Notre Dame Press, Notre Dame.

Arthur, J. (ed.), 2005, 'Morality, religion, and conscience', in Morality and moral controversies: Readings in moral, social, and political philosophy, pp. 15-23, Prentice Hall, Upper Saddle River.

Audi, R. \& Wainwright, W., 1986, Rationality, religious belief, and moral commitment, Cornell University Press, Ithaca.

Barton, J., 2003, Understanding Old Testament ethics, Westminster John Knox Press, Louisville.

Carroll, R.P., 1991, Wolf in the sheepfold: The Bible as a problem for Christianity, SPCK, London.

Copan, P., 2003, 'Morality and meaning without God: Another failed attempt', Philosophia Christi ser. 2(6), 295-304.

Crenshaw, J.L., 1980, The divine helmsman: Studies on God's control of human events, KTAV Publishing House Inc, New York.

Crenshaw, J.L., 1983, Theodicy in the Old Testament, IRT 4, Fortress Press, Philadelphia.

Crenshaw, J.L., 1984, A whirlpool of torment: Israelite traditions of God as an oppressive presence, Fortress Press, Minneapolis.

Davidson, R., 1997, The courage to doubt, SCM Press, London.

Davies, A., 2000, Double standards in Isaiah, Brill, Leiden.

Eichrodt, W., 1967, Theology of the Old Testament, vol. 2, Westminster Press, Philadelphia.

Frame, J.M., Euthyphro, Hume, and the biblical God, viewed 13 February 2007, from http://www.frame-poythress.org/ frame_articles/1993Euthyphro.htm.

Gericke, J.W., 2005, 'Beyond reconciliation - monistic Yahwism and the problem of evil in philosophy of religion', Verbum et Ecclesia 26(1), 64-92.

Gericke, J.W., 2007, 'The quest for a philosophical YHWH (part 3) - Towards a philosophy of Old Testament religion', Old Testament Essays 20(3), 669-688.

Hare, J., 1997, The moral gap: Kantian ethics, human limits, and God's assistance, Oxford University Press, New York.

Hare, J., 2008, 'Religion and morality', in E.N. Zalta (ed.), The Stanford Encyclopedia of Philosophy (Fall 2008 Edition), viewed 29 March 2009, from http://plato.stanford.edu/archives/ fall2008/entries/religion-morality/.

Helm, P., 1981, Divine commands and morality, Oxford University Press, Oxford.

Kant, I., 1993, Critique of practical reason, 3rd edn., transl. L. White Beck, Prentice Hall, Upper Saddle River.

Kierkegaard, S., 1985, Fear and trembling, transl. A. Hannay, Penguin, New York.

Knierim, R.P., 1995, The task of Old Testament theology, Eerdmans, Grand Rapids.

Knight, D., 1982, Christian Century, viewed 25 February 2009, from http://www.religion-online.org/showarticle. asp?title $=1276$.
Kretzmann, N., 1983, 'Abraham, Isaac, and Euthyphro: God and the basis of morality', in D.V. Stump, J.A. Arieti, L. Gerson \& E. Stump (eds.), 'Hamartia', the concept of error in the Western tradition: Essays in honor of John M. Crossett, pp. 27-50, Edwin Mellen Press, New York.

Leibniz, G., 1951, Theodicy, Routledge, London.

Mackie, J.L., 1977, Ethics: Inventing right and wrong, Penguin Books, New York.

Matthews, G.B., 1995, 'Euthyphro problem', in T. Honderich (ed.), The Oxford Companion to Philosophy, p. 253, Oxford University Press, Oxford.

Morris, T.V., 1987, 'Duty and divine goodness', in T.V. Morris (ed.), The concept of God, pp. 107-121, Oxford University Press, Oxford.

Morris, T.V., 1991, Our idea of God: An introduction to philosophical theology, University of Notre Dame Press, Notre Dame.

Morriston, W., 2001, 'Must there be a standard of moral goodness apart from God?' Philosophia Christi ser. 2(3), 127-138.

Mouw, R., 1970, 'The status of God's moral judgment', Canadian Journal of Theology 16, 61-66.

Mouw, R., 1990, The God who commands, University of Notre Dame Press, Notre Dame.

Murphy, M., 1998, 'Divine command, divine will, and moral obligation', Faith and Philosophy 15, 3-27.

Nielsen, K., 1973, Ethics without God, Prometheus Books, Buffalo.

Otto, E., 1994, Theologischeethikdes Alten Testaments, Theologische Wissenschaft 3(2), Kohlhammer, Stuttgart.

Plato, 1981, Five dialogues: Euthyphro, Apology, Crito, Meno, Phaedo, transl. G.M.A. Grube, Hackett Publishing Company, Indianapolis.

Preuss, H.-D., 1992, Theology of the Old Testament, vol. 2, Kohlhammer, Stuttgart.

Quinn, P.L., 1979, 'Divine command ethics: A causal theory', in J. Idziak (ed.), Divine command morality: Historical and contemporary readings, pp. 305-325, Edwin Mellen Press, New York.

Quinn, P.L., 1987, Divine commands and moral requirements, Clarendon Press, Oxford.

Stump, E. 2001. 'Evil and the nature of faith', in Calvin College and Calvin Theological Seminary (eds.), Seeking Understanding: The Stob Lectures 1986-1998, pp. 530-550, Eerdmans, Grand Rapids.

Wainright, W.J., 2005, Religion and morality, Ashgate, Burlington.

Wierenga, E., 1989, The nature of God: An inquiry into divine attributes, Cornell University Press, Ithaca.

Wierenga, E., 2003, 'A defensible Divine Command Theory', Nous $17,387-407$.

Zagzebski, L., 2004, Divine motivation theory, Cambridge University Press, New York. 